\title{
Professional education on dementias in Primary Health Care: an integrative review
}

\author{
Educação profissional sobre demências na atenção primária à saúde: revisão integrativa \\ Educación profesional sobre demencias en la atención primaria de salud: revisión integrativa
}

\section{Gislaine Desani da Costa' \\ ORCID: 0000-0002-0672-6764}

Vívian Marina Calixto Damasceno Spineli' ORCID: 0000-0003-0039-7602

Maria Amélia de Campos Oliveira' ORCID: 0000-0002-0533-7193

'Universidade de São Paulo. São Paulo, São Paulo, Brazil.

How to cite this article:

Costa GD, Spineli VMCD, Oliveira MAC. Professional education on dementias in Primary Health Care: an integrative review. Rev Bras Enferm. 2019;72(4):1086-93. doi: http://dx.doi.org/10.1590/0034-7167-2018-0652

\section{Corresponding Author:}

Gislaine Desani da Costa

E-mail: gislaine_desani@hotmail.com

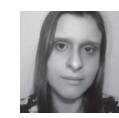

Submission: 08-07-2018

Approval: 10-20-2018

\begin{abstract}
Objective: To investigate the most commonly used educational approaches in dementia training for primary health care professionals. Method: Integrative literature review, conducted between April and June of 2018, in PubMed, LILACS and IBECS databases. The descriptors used were: Training, Health Personnel, Dementia, Primary Health Care for PubMed; and the MeSH terms, Training Programs, Health Personnel, Dementia, and Primary Health Care for LILACS and IBECS. Results: The sample consisted of 13 articles; eight were published in the last five years (62\%); seven articles with a quantitative approach (54\%); seven articles produced on the European continent (54\%), followed by five published on the North American continent (38\%). All journals were from the health area (100\%). Conclusion: Educational strategies were combined and used for education. Significant improvements in knowledge, skills, and attitudes of the teams with regard to professional management of dementias were evidenced. Descriptors: Education; Inservice Training; Health Personnel; Dementia; Primary Health Care.
\end{abstract}

\section{RESUMO}

Objetivo: Investigar as abordagens educativas mais comumente utilizadas na capacitação em demência para profissionais da Atenção Primária à Saúde. Método: Revisão integrativa de literatura, realizada entre abril e junho de 2018, nas bases de dados: PubMed, LILACS e IBECS. Foram utilizados os descritores Training, Health Personnel, Dementia, Primary Health Care para PubMed e os termos Mesh Training Programs, Health Personnel, Dementia, Primary Health Care, para LILACS e IBECS. Resultados: A amostra foi composta por 13 artigos, sendo oito publicados nos últimos 5 anos (62\%); sete artigos com abordagem quantitativa (54\%); sete artigos produzidos no continente europeu (54\%), seguidos de cinco publicados no continente norte-americano (38\%). Quanto aos periódicos, todos eram da área da saúde (100\%). Conclusão: Algumas estratégias educacionais foram combinadas e utilizadas para a capacitação. Melhorias significativas em conhecimento, habilidades e atitudes das equipes no acompanhamento às demências foram evidenciadas.

Descritores: Educação; Capacitação em Serviço; Pessoal de Saúde; Demência; Atenção Primária à Saúde.

\section{RESUMEN}

Objetivo: Investigar los enfoques educativos más utilizados en la educación sobre demencia para profesionales de atención primaria de salud. Método: Revisión integrativa de la literatura, realizada entre abril y junio de 2018 , utilizando las bases de datos PubMed, LILACS e IBECS. Los descriptores, entrenamiento, personal de salud, demencia y atención primaria de salud se utilizaron en PubMed; los términos Mesh, Programas de capacitación, Personal de salud, Demencia y Atención primaria de salud se utilizaron en LILACS e IBECS. Resultados: La muestra constó de 13 artículos, ocho fueron publicados en los últimos cinco años (62\%); siete artículos tuvieron un enfoque cuantitativo (54\%); se produjeron siete artículos en el continente europeo (54\%), seguidos de cinco publicados en el continente norteamericano (38\%). Todas las revistas fueron del área de salud (100\%). Conclusión: Las estrategias educativas se combinaron y se utilizaron para la enseñanza. Se evidenciaron mejoras significativas en el conocimiento, las habilidades y las actitudes de los equipos con respecto a la gestión profesional de las demencias.

Descriptores: Education; Inservice Training; Health Personnel; Dementia; Primary Health Care. 


\section{INTRODUCTION}

Dementias are one of the leading causes of disability in the elderly. In 2010, it was estimated that there would be a total of 35.6 million people living with this syndrome worldwide. Projections indicate that this number doubles every 20 years, and can reach 65.7 million in 2030 and 115.4 million in 2050 . Around 7 million new cases of dementia occur worldwide each year, or a new case every 4 seconds, distributed as follows: 3.6 million (46\%) in Asia, 2.3 (31\%) in Europe; 1.2 (16\%) in the Americas, and half a million (7\%) in Africa ${ }^{(1-2)}$.

A meta-analysis from Brazil, whose aim was to calculate the prevalence rate, and project the growth of the number of elderly people with dementia in the near future, identified a general prevalence rate of approximately $7.6 \%$, higher for Alzheimer's disease, at approximately $54 \%$ of cases; rates increased with age, and were higher among women. When estimated along with the aging population, in 2020 this rate will be $7.9 \%$. The study also predicted the incidence of 2.7 new cases of dementia in every 1,000 elderly / year ${ }^{(1)}$.

In the Brazilian context, the task of caring for a dependent elderly person, in general, rests with close family members, who are usually female, as partners and daughters. This practice reduces the costs of hospital and institutional care for elderly with disabilities; staying at home under the care of their family aims to improve their comfort and dignity, despite representing a burden for most families.

In caring for those suffering with dementias, family members are suddenly given caregiver status and are faced with multiple challenging tasks, ranging from accepting the diagnosis, to reprogramming their routines to include care-related activities, as well as providing financial and legal support to the family member with dementia. Most of the time, caring for these patients is a solitary act, with no guarantee of retribution, recognition, or affection, which can give rise to ambiguous feelings in the caregiver related to the elderly individual, such as anger, guilt, anguish, and fear. On the other hand, feelings of affection, love, and gratitude can arise, as a way of repaying the care they received at another time in life. With the progression of the disease, the demand for care also increases, leading to an increase in difficulties and, consequently, an overload ${ }^{(3-8)}$.

Health professionals can help to reduce the tension between the patient and those responsible for his care, by knowing how to recognize the symptoms of the disease and guiding caregivers effectively. In general, caregivers benefit from the educational and emotional support provided by the health professional ${ }^{(3-4,9)}$.

The global community recently recognized the need for actions to place dementia on the public health agenda. The high prevalence of dementia, its economic impact on caregivers, families and communities, as well as the stigma and social exclusion associated with the disease, are major challenges, especially in countries that are aging rapidly, such as Brazil ${ }^{(2)}$.

In most western countries, primary care services are in a better position to provide comprehensive health care for patients with dementia ${ }^{(10)}$ than they are in Brazil. The Ministry of Health has developed permanent education proposals for health professionals to be able to promote active and healthy aging. In fact, health workers have a special role in collaborating so that more people reach advanced age in the best possible health condition. In an expanded way, health requires substantial changes to construct a social and cultural environment that is more favorable to the elderly. In the Family Health Strategy (FHS) teamwork, the group activities, collective actions in the community, and social network communication of patients are some of the resources necessary for action in the cultural and social dimensions ${ }^{(11)}$.

Given the acceleration of aging in the last decades, the Municipal Health Secretariat of São Paulo proposed the adoption of the Multidimensional Assessment of Elderly Persons in Primary Care (AMPI-AB) instrument to the health services network in primary health care $(\mathrm{PHC})$, and trained some professionals to provide care to this part of the population. This instrument has the objective of assisting PHC professionals in meeting the demands of the elderly, and in managing their health care ${ }^{(12)}$.

Continuing education of the health workforce is essential to improve knowledge and understanding of the benefits of a coordinated response to the health needs of people, especially the elderly, given that projections indicate that our country will be the sixth in numbers of elderly in $2025^{(2)}$.

\section{OBJECTIVE}

To investigate the most commonly used educational approaches in dementia training for primary health care $(\mathrm{PHC})$ professionals.

\section{METHODS}

An integrative review of the literature was performed, the purpose of which is to gather and synthesize the pre-existing knowledge about a certain theme. This method provides a global understanding of the phenomenon analyzed through the synthesis of the knowledge produced, as it includes experimental and non-experimental studies, and involves six steps: identification of the theme and selection of the research question, establishment of criteria for inclusion and exclusion of studies, evaluation of studies included in the integrative review, determination of information to be extracted from selected studies, interpretation of results, presentation and dissemination of results ${ }^{(13-14)}$.

The theme of this production was based on the following guiding question: "What educational approaches described in the scientific literature are adopted for training PHC professionals about dementia?"

The online databases used to obtain the sample for this study were: PubMed, Latin American and Caribbean Literature in Health Sciences (LILACS) and Índice Bibliográfico Español en Ciencias de la Salud (IBECS). The Medical Subject Heading (MeSH) terms used in PubMed were: Training Programs AND Health Personnel AND Dementia AND Primary Health Care. In LILACS and IBECS, the Health Sciences Descriptors were: Training AND Health Personnel AND Dementia AND Primary Health Care were used. Primary and secondary published articles describing educational strategies or dementia education programs for PHC professionals, published in the last fifteen years (2004 to 2018), in English and Spanish, were included.

The data collection occurred from April to June of 2018, and was conducted in two stages. The first stage consisted of searching for articles in the databases: PubMed-30; LILACS-2; IBECS-7. In the second phase, the titles (PubMed-92; LILACS-0; IBECS-0), the abstracts (PubMed-35) and, finally, the articles were analyzed in order to identify the educational strategies used in $\mathrm{PHC}$ with regard to dementia (PubMed-13). The reasons for exclusion of 
articles obtained in the first search were, studies that described education for $\mathrm{PHC}$ health professionals on the theme "cognitive disorders in general", those that described training in dementia for informal caregivers, and those which described dementia training outside the context of PHC. Figure 1 illustrates the selection process for the articles in this review.

The thirteen articles selected were analyzed using a form prepared by the authors, with items related to: a) study identification data (article title, year of publication, periodical, and type of publication); b) objective of the study; c) study design (experimental, quasiexperimental, non-experimental), and the different models within

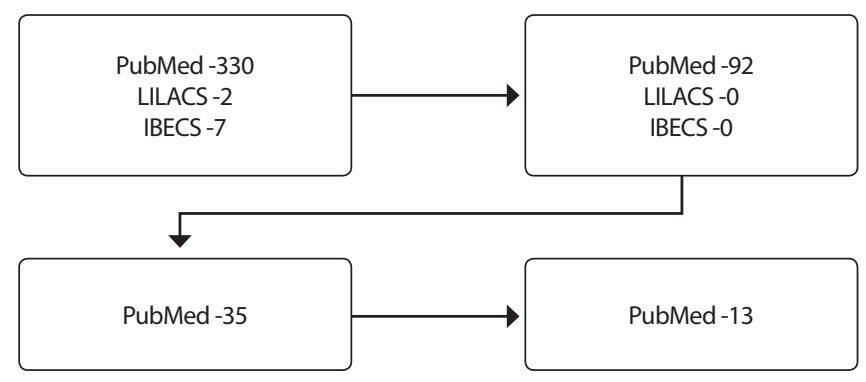

Figure 1 - Flowchart of the identification, selection, and inclusion of articles for the integrative review, São Paulo, Brazil, 2018 the later category (e.g., correlational, prospective, retrospective, survey, documentary, or bibliographic studies); d) strategies used in dementia training of $\mathrm{PHC}$ professionals; e) categories of professionals who received the training. The articles were read in depth, and analyzed critically to ensure the validity of the review ${ }^{(14)}$. The data identified were transcribed, organized, and stored in a Microsoft Office Excel ${ }^{\circledR}$ worksheet. The resulting synthesis is shown below.

\section{RESULTS}

The characterization of the corpus demonstrated that the thirteen selected studies were in the English language, published mostly in the last five years $(n=8)$, with a quantitative approach predominating (quasi-experimental, $n=4$; clinical trials, $n=3$ ), and were from the European continent, which had seven published articles (England, $n=3$; the Netherlands, $n=3$; and Germany, $n=1$ ), followed by five articles published on the North American continent (United States of America, $n=3$; Canada, $n=2$ ). All of the articles were from the health area (medicine, $\mathrm{n}=11$; health education, $\mathrm{n}=1$; and nursing, $\mathrm{n}=1$ ).

Charts 1 and 2 present the general panorama of the thirteen publications, highlighting the objectives of the studies, the educational strategies adopted for training of the $\mathrm{PHC}$ health professionals on dementia, and the outcomes of the educational intervention studies.

Chart 1 - Distribution of the articles included in the integrative review, based on the objectives of the studies, and educational strategies used for training primary health care health professionals on dementia, published from 2004 to 2018, São Paulo, Brazil, 2018

\begin{tabular}{|c|c|c|c|c|}
\hline $\mathbf{n}$ & Title/ Year/ Journal & $\begin{array}{c}\text { Study design / } \\
\text { Sample }\end{array}$ & Objective & Educational strategies \\
\hline 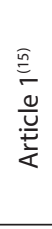 & $\begin{array}{l}\text { Dementia care management } \\
\text { in primary care: current } \\
\text { collaborative care models and } \\
\text { the case for interprofessional } \\
\text { education, } 2017 . \\
\text { Gerontologie und Geriatrie }\end{array}$ & $\begin{array}{l}\text { Descriptive- } \\
\text { exploratory. } \\
\text { Six programs of } \\
\text { management } \\
\text { of caring in } \\
\text { dementia }\end{array}$ & $\begin{array}{l}\text { To describe the } \\
\text { international models of } \\
\text { interprofessional care } \\
\text { in dementia to define a } \\
\text { minimum standard for PHC } \\
\text { professionals' care. }\end{array}$ & $\begin{array}{l}\text { In-class theoretical classes; virtual platforms with } \\
\text { distance theoretical classes with the opportunity for } \\
\text { questioning, analysis, and discussion of case studies } \\
\text { with interdisciplinary participation; cases discussed by } \\
\text { the team on an ongoing basis. }\end{array}$ \\
\hline 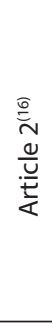 & $\begin{array}{l}\text { Triple aim improvement for } \\
\text { individuals, services and } \\
\text { society in dementia care: the } \\
\text { DementiaNet collaborative care } \\
\text { approach, } 2017 . \\
\text { Gerontologie und Geriatrie }\end{array}$ & Descriptve. & $\begin{array}{l}\text { To describe the Dutch } \\
\text { model of interdisciplinary } \\
\text { collaborative practice } \\
\text { in dementia care, The } \\
\text { DementiaNet. }\end{array}$ & $\begin{array}{l}\text { Encouraging the use of practical tools to improve } \\
\text { the quality of dementia care; continuous assessment } \\
\text { of knowledge, attitudes, skills, collaboration in care, } \\
\text { and quality of care provided in dementia; selection } \\
\text { of problems with formulation of action plan (PDCA } \\
\text { cycle); organization of interdisciplinary training based } \\
\text { on identified problems (theoretical classes on topics } \\
\text { related to dementia and teamwork, discussion of cases); } \\
\text { use of electronic communication tools to discuss cases, } \\
\text { coordination of actions, and specialization in dementia }\end{array}$ \\
\hline 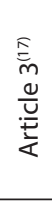 & $\begin{array}{l}\text { The Many Faces of Dementia: is an } \\
\text { online course beneficial for GPs? } \\
2017 . \\
\text { British Journal of General Practice }\end{array}$ & Analitical. & $\begin{array}{l}\text { To analyze whether The } \\
\text { Many Faces of Dementia } \\
\text { course is beneficial to the } \\
\text { family physician. }\end{array}$ & $\begin{array}{l}\text { The Many Faces of Dementia - free online course to } \\
\text { provide a better understanding of current presentation, } \\
\text { symptoms, challenges, and current research on } \\
\text { dementia: theoretical classes; videos sharing the } \\
\text { experiences of people with dementia, family caregivers, } \\
\text { health professionals, and researchers in the area. }\end{array}$ \\
\hline 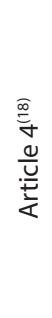 & $\begin{array}{l}\text { Evaluation of a nurse-led } \\
\text { Dementia Education and } \\
\text { Knowledge Translation } \\
\text { Programme in primary care: a } \\
\text { cluster randomized controlled } \\
\text { trial, } 2017 . \\
\text { Nurse Education Today }\end{array}$ & $\begin{array}{l}\text { Randomized } \\
\text { controlled trial. } \\
\\
85 \text { professional } \\
\text { intervention } \\
\text { group and } 85 \\
\text { professional } \\
\text { control group }\end{array}$ & $\begin{array}{l}\text { To determine the } \\
\text { effectiveness of a dementia } \\
\text { education program for } \\
\text { PHC professionals, their } \\
\text { satisfaction with the } \\
\text { program, and to understand } \\
\text { their perceptions and } \\
\text { experiences with the subject } \\
\text { of the program. }\end{array}$ & $\begin{array}{l}\text { Dementia Education and Knowledge Translation Program } \\
\text { - Dementia education program with } 10 \text { modules (total of } \\
20 \text { hours): selection of a nurse and a physician for program } \\
\text { trainers on the unit (three-day classroom training workshop, } \\
\text { each module covers pre-reading, short lecture, and case } \\
\text { study, with group presentation and discussion); teaching } \\
\text { and learning resources for coaches (one workbook and four } \\
\text { DVDs); ongoing support from the project team to coaches } \\
\text { through email, telephone, and visits to the unit during the } \\
\text { implementation phase of the program. }\end{array}$ \\
\hline
\end{tabular}




\begin{tabular}{|c|c|c|c|c|}
\hline $\mathbf{n}$ & Title/ Year/ Journal & $\begin{array}{c}\text { Study design / } \\
\text { Sample }\end{array}$ & Objective & Educational strategies \\
\hline 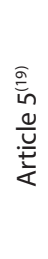 & $\begin{array}{l}\text { The development and } \\
\text { evaluation of an educational } \\
\text { intervention for primary care } \\
\text { promoting person-centred } \\
\text { responses to dementia, } 2015 . \\
\text { Dementia }\end{array}$ & $\begin{array}{c}\text { Quasi } \\
\text { experimental. } \\
94 \text { professionals }\end{array}$ & $\begin{array}{l}\text { To describe the development } \\
\text { of an educational } \\
\text { intervention project based } \\
\text { on the results of the work of } \\
\text { a focus group; pilot testing } \\
\text { and improvement of training } \\
\text { materials; field test and } \\
\text { intervention evaluation. }\end{array}$ & $\begin{array}{l}\text { One-hour expository course (introduction to dementia } \\
\text { and subtypes, followed by early diagnosis, introduction } \\
\text { to the concept of approaches focused on the person } \\
\text { with dementia, based on the interviews extracts with } \\
\text { people with dementia and their caregivers); expository } \\
\text { presentation manual; four case study examples for } \\
\text { discussion; training manual with detailed guidelines for } \\
\text { managing dementia care. }\end{array}$ \\
\hline 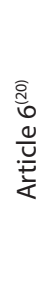 & $\begin{array}{l}\text { Tailored educational } \\
\text { intervention for primary care } \\
\text { to improve the management } \\
\text { of dementia: the EVIDEM-ED } \\
\text { cluster randomized controlled } \\
\text { trial, } 2013 . \\
\text { Trials }\end{array}$ & $\begin{array}{l}\text { Randomized } \\
\text { controlled trial. } \\
512 \text { patients } \\
\text { intervention } \\
\text { group } \\
560 \text { patients } \\
\text { control group }\end{array}$ & $\begin{array}{l}\text { Test the effect of an } \\
\text { adapted workplace-based } \\
\text { educational intervention } \\
\text { developed for general } \\
\text { clinical practice in the } \\
\text { management of people with } \\
\text { dementia. }\end{array}$ & $\begin{array}{l}\text { Identification of the educational needs in PHC; } \\
\text { discussion workshops in the work environment; } \\
\text { virtual platforms with distance theoretical classes and } \\
\text { possibilities to clarify concerns; workshops (interactive } \\
\text { lectures, presentations, discussion of cases, group } \\
\text { activities, and multimedia presentations). }\end{array}$ \\
\hline 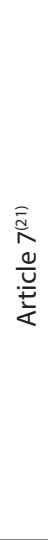 & $\begin{array}{l}\text { Developing memory clinics } \\
\text { in primary care: an evidence- } \\
\text { based interprofessional } \\
\text { program of continuing } \\
\text { professional development, } \\
2013 . \\
\text { Journal of Continuing } \\
\text { Education in the Health } \\
\text { Professions }\end{array}$ & $\begin{array}{c}\text { Quasi } \\
\text { experimental. } \\
124 \text { professionals }\end{array}$ & $\begin{array}{l}\text { To describe an innovative } \\
\text { approach to a dementia } \\
\text { training and management } \\
\text { program based on } \\
\text { interprofessional } \\
\text { memory clinics for PHC } \\
\text { professionals. }\end{array}$ & $\begin{array}{l}\text { Dementia Training Program (five days): seminar (two } \\
\text { days) - explanation on the differentiation of normal aging, } \\
\text { cognitive disorder, and dementia; presentation of the main } \\
\text { types of dementia, screening, diagnosis, pharmacological } \\
\text { and non-pharmacological management, family support, } \\
\text { and dementia monitoring; workshop (two days) consisting } \\
\text { of several modules on dementia assessment and } \\
\text { management - interactive lectures, practical training on } \\
\text { how to apply cognitive tests, presentation and discussion } \\
\text { of eight cases, group activities, multimedia presentations, } \\
\text { online research before each module for the educational } \\
\text { needs and specific interests of the participants; mentoring } \\
\text { program (one day) - observation of the professionals' } \\
\text { actions by video, and personal presence in discussions } \\
\text { in which evaluation results were reviewed and plans for } \\
\text { management in dementia were formulated; two-day } \\
\text { follow-up of apprenticeship by program mentors. }\end{array}$ \\
\hline 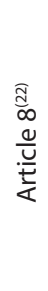 & $\begin{array}{l}\text { Improving physician awareness } \\
\text { of Alzheimer disease and } \\
\text { enhancing recruitment: the } \\
\text { Clinician Partners Program, } \\
2012 . \\
\text { Alzheimer Disease and } \\
\text { Associated Disorders }\end{array}$ & $\begin{array}{c}\text { Quasi } \\
\text { experimental. } \\
146 \text { professionals }\end{array}$ & $\begin{array}{l}\text { To provide educational } \\
\text { opportunities to rural PHC } \\
\text { providers to learn about } \\
\text { Alzheimer's disease (AD) } \\
\text { and related disorders, } \\
\text { to improve diagnosis, } \\
\text { treatment, and dementia- } \\
\text { related care for the benefit } \\
\text { of rural seniors. }\end{array}$ & $\begin{array}{l}\text { Clinical Partner Program: mini-residence (three days), } \\
\text { seminars, and clinical meetings with discussion of } \\
\text { cases (didactic teaching techniques, observational } \\
\text { and practical); handbook for practice - useful articles, } \\
\text { tracking tools, diagnostic criteria, and practice } \\
\text { guidelines. }\end{array}$ \\
\hline 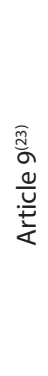 & $\begin{array}{l}\text { Building capacity for dementia } \\
\text { care: training program to } \\
\text { develop primary care memory } \\
\text { clinics, } 2011 . \\
\text { Canadian Family Physician }\end{array}$ & Descriptive. & $\begin{array}{l}\text { To develop highly } \\
\text { functional interprofessional } \\
\text { memory clinics that } \\
\text { assist family physicians in } \\
\text { providing quality care to } \\
\text { patients with dementia } \\
\text { and other forms of } \\
\text { cognitive impairment. }\end{array}$ & $\begin{array}{l}\text { Training Program in Memory Clinics: interactive } \\
\text { workshop, with case discussion ( } 2 \text { days) - explanation } \\
\text { about the differentiation of normal aging, cognitive } \\
\text { disorder, and dementia; presentation of the main types } \\
\text { of dementia, screening, diagnosis, pharmacological and } \\
\text { non-pharmacological management, family support, and } \\
\text { dementia monitoring; observation and clinical training } \\
\text { in memory clinics and family medicine (one day), and } \\
\text { mentoring in memory clinics (two days); } \\
\text { Providing of detailed training manual, with references on } \\
\text { the subject noted; constant update, according to schedule. }\end{array}$ \\
\hline 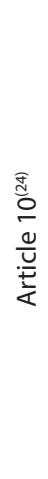 & $\begin{array}{l}\text { Effects of educational } \\
\text { interventions on primary } \\
\text { dementia care: a systematic } \\
\text { review, } 2011 . \\
\text { International Journal of } \\
\text { Geriatric Psychiatry }\end{array}$ & $\begin{array}{l}\text { Narrative review. } \\
\text { 1,904 primary care } \\
\text { providers (PCPs) }\end{array}$ & $\begin{array}{l}\text { To determine the effects of } \\
\text { educational interventions } \\
\text { on dementia directed at } \\
\text { PCPs. }\end{array}$ & $\begin{array}{l}\text { Six studies: 1) multifaceted intervention: four seminars, } \\
\text { additional extension visits, small group training; } 2 \text { ) small } \\
\text { group workshop (10 practice sessions), decision support } \\
\text { system (8 practice sessions), electronic tutorial on CD-ROM } \\
\text { (8 practice sessions); } 3 \text { ) multifaceted intervention: direct } \\
\text { learning, through } 100 \text { minutes of interactive seminars, } \\
\text { divided into up to } 5 \text { sessions, combined with booklets } \\
\text { and website containing information on seminars); indirect } \\
\text { learning through collaboration with the service manager; } \\
\text { 4) multifaceted intervention: introduction of dementia } \\
\text { care managers; training of primary care providers - } 90 \\
\text { minutes of interactive seminars, standardized in up to five } \\
\text { sessions; } 5 \text { ) an extensive and partially interactive seminar } \\
\text { on diagnosis and management of dementia (five hours); 6) } \\
\text { educational group meeting (two hours). }\end{array}$ \\
\hline
\end{tabular}




\begin{tabular}{|c|c|c|c|c|}
\hline $\mathbf{n}$ & Title/ Year/ Journal & $\begin{array}{c}\text { Study design / } \\
\text { Sample }\end{array}$ & Objective & Educational strategies \\
\hline 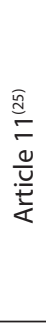 & $\begin{array}{l}\text { Can an EASYCare based } \\
\text { dementia training programme } \\
\text { improve diagnostic assessment } \\
\text { and management of dementia } \\
\text { by general practitioners and } \\
\text { primary care nurses? The design } \\
\text { of a randomised controlled trial, } \\
2008 \text {. } \\
\text { BMC Health Services Research }\end{array}$ & Descriptive. & $\begin{array}{l}\text { To describe the design } \\
\text { of a randomized } \\
\text { controlled intervention } \\
\text { study to determine } \\
\text { the effectiveness of a } \\
\text { multifaceted Dementia } \\
\text { Training Program (DTP) for } \\
\text { general practitioners and } \\
\text { PHC nurses. }\end{array}$ & $\begin{array}{l}\text { EASYCare (DTP): multifaceted educational intervention } \\
\text { program consisting of two workshops (diagnosis, dementia } \\
\text { management, pharmacological and non-pharmacological } \\
\text { management, support to family members); coaching } \\
\text { program, with follow-up of specialists in select cases } \\
\text { identified for follow-up in practice (nine months); access to } \\
\text { an internet forum for discussion of interprofessional cases, } \\
\text { additional literature, and individual training on diagnosis } \\
\text { and treatment of dementia; and a computerized clinical } \\
\text { decision support system on dementia diagnoses. }\end{array}$ \\
\hline 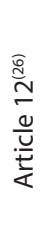 & $\begin{array}{l}\text { Effect of a dementia care } \\
\text { management intervention on } \\
\text { primary care provider knowledge, } \\
\text { attitudes, and perceptions of } \\
\text { quality of care, } 2006 . \\
\text { Journal of the American Geriatrics } \\
\text { Society }\end{array}$ & $\begin{array}{l}\text { Randomized } \\
\text { controlled trial. } \\
232 \text { professionals }\end{array}$ & $\begin{array}{l}\text { To evaluate the effect of a } \\
\text { multicomponent dementia } \\
\text { care management program } \\
\text { on the knowledge of PCPs, } \\
\text { attitudes and perceptions } \\
\text { about the quality of care } \\
\text { provided in dementia. }\end{array}$ & $\begin{array}{l}\text { Five educational modules in dementia (100 minutes): } \\
\text { overview presentation of the dementia management } \\
\text { program; role of care managers; presentation of care } \\
\text { protocols; diagnosis and treatment of dementias; } \\
\text { assessment of medical decision-making capacity; } \\
\text { providing online training material and handing out } \\
\text { brochures. }\end{array}$ \\
\hline 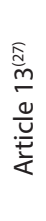 & $\begin{array}{l}\text { Interventions to improve quality } \\
\text { of care: the Kaiser Permanente- } \\
\text { alzheimer's Association Dementia } \\
\text { Care Project, } 2004 \text {. } \\
\text { The American Journal of } \\
\text { Managed Care }\end{array}$ & $\begin{array}{l}\text { Quasi } \\
\text { experimental. } \\
83 \text { patients and } \\
\text { their caregivers }\end{array}$ & $\begin{array}{l}\text { To improve the quality } \\
\text { of care for dementia by } \\
\text { rigorously disseminating } \\
\text { practical guidelines and } \\
\text { social worker support for } \\
\text { physicians and patients. }\end{array}$ & $\begin{array}{l}\text { 24-hour theoretical-practical course for care managers } \\
\text { (social worker), followed by } 7 \text { months of case orientation } \\
\text { through conferences; theater (simulation of real cases); } \\
\text { tool kit (two guidelines for dementia care and screening } \\
\text { tests for dementia and depression). }\end{array}$ \\
\hline
\end{tabular}

Chart 2 - Outcomes of dementia education intervention studies for primary health care professionals, published from 2004 to 2018, São Paulo, Brazil, 2018

\begin{tabular}{|c|c|c|}
\hline Study & Trained Professionals & Outcome \\
\hline Article $4^{(18)}$ & $\begin{array}{l}\text { Nurse and } \mathrm{PHC} \text { general } \\
\text { practitioner }\end{array}$ & $\begin{array}{l}\text { - Statistically significant effect of the program on the knowledge, attitude, and approach of } \\
\text { person-centered care in relation to the control group; } \\
\text { - Focus groups stated that the program had a positive impact on their practice in dementia care. }\end{array}$ \\
\hline Article $5^{(19)}$ & $\begin{array}{l}\text { Nurse, general practitioner, and } \\
\text { PHC manager }\end{array}$ & $\begin{array}{l}\text { - After training, a statistically significant effect was identified in the understanding of person- } \\
\text { centered care, focused on patients with dementia; actions for early diagnosis; awareness of } \\
\text { the symptoms of non-cognitive dementia, and awareness of the role that nonclinical staff } \\
\text { members can play in the recognition of dementia. }\end{array}$ \\
\hline Article $6^{(20)}$ & $\begin{array}{l}\text { Nurse and family physician, } \\
\text { social worker, psychologist, } \\
\text { PHC occupational therapist, } \\
\text { physiotherapist, and pharmacist }\end{array}$ & $\begin{array}{l}\text { - No statistically significant difference was identified in the detection of dementia cases } \\
\text { between the intervention group and the control group. }\end{array}$ \\
\hline Article $7^{(21)}$ & $\begin{array}{l}\text { Nurse and family physician, } \\
\text { social worker, psychologist, } \\
\text { occupational therapist, PHC } \\
\text { pharmacist, and representative } \\
\text { of the Alzheimer's Society }\end{array}$ & $\begin{array}{l}\text { - Statistically significant increase in self-reported knowledge and ability to assess and manage } \\
\text { cognitive impairment, confidence, comfort level in talking to patients about memory problems, } \\
\text { and the ability of family health teams to independently manage cognitive impairment; } \\
\text { - Increased engagement in dementia care practice activities; } \\
\text { - } 96 \% \text { of family health teams developed a memory clinic. }\end{array}$ \\
\hline Article $8^{(22)}$ & $\begin{array}{l}\text { PHC general practitioner, } \\
\text { advanced practice nurse, } \\
\text { medical assistant, psychologist, } \\
\text { and social worker }\end{array}$ & $\begin{array}{l}\text { - Statistically significant improvement of knowledge and confidence for the diagnosis and } \\
\text { treatment of dementia; } \\
\text { - Increased use of screening tools for dementia; } \\
\text { - A } 52 \% \text { increase in participation in rural referral to an urban Alzheimer's disease research center. }\end{array}$ \\
\hline Article $12^{(26)}$ & $\begin{array}{l}\text { Nurse, family physician, } \\
\text { medicine student }\end{array}$ & $\begin{array}{l}\text { - Intervention group improved its knowledge on evaluation of the decision-making capacity } \\
\text { in dementia, than the control group; } \\
\text { - Intervention group considered dementia patients to be more difficult to manage in PHC } \\
\text { than the control group; } \\
\text { - No other differences were found in knowledge, attitudes, or perceptions of quality of care } \\
\text { between the intervention and the control groups. }\end{array}$ \\
\hline Article $13^{(27)}$ & Family physician, social worker & $\begin{array}{l}\text { - Higher rates of provider and caregiver satisfaction with the dementia care system were found at } \\
\text { post-intervention follow-up, as compared with baseline values; } \\
\text { - Significantly higher rates of adherence to several quality measures based on the practice } \\
\text { guideline: assessment of cognitive status; referrals to the Alzheimer's Association, evaluations of } \\
\text { daily living activities, decision making ability, depression, and behavioral changes. }\end{array}$ \\
\hline
\end{tabular}




\section{DISCUSSION}

Most of the publications selected in the study were from the last decade, which indicates that the theme is extremely current $^{(15-22)}$. Countries with a higher rate in the number of elderly and in life expectancy have been organizing to identify cases of dementia within PHC, because the professionals at this level of care have a greater proximity to the population and, therefore, a greater potential for detection and follow-up of the cases, with possible referral to specialized services ${ }^{(15-27)}$.

Two intervention studies that evaluated the impact of dementia training on referrals to specialized institutions found an increase in their respective rates. In the first, the number of referrals increased from $6 \%$ to $12.8 \%$ in three years, an increase of approximately $52 \%{ }^{(22)}$. In the second, the increase was self-reported by professionals and less expressive, from $58 \%$ to $63 \%$ of the number of physicians who answered that they sometimes or always referred their patients to the specialized service ${ }^{(27)}$.

With regards to the strategies used for dementia training, 100\% ( $n=13$ ) of the studies used theoretical classes with an explanation about dementia ${ }^{(15-27)}$; twelve (92\%) used case discussion and considered the work environment as an essential part of the learning process ${ }^{(15-16,18-27)}$; eleven (85\%) provided material for additional reference( ${ }^{15-20,23-27)}$; nine (69\%) used electronic communication tools/virtual platforms $s^{(15-18,20-21,}$ 24-26); six (46\%) mentioned the use of workshops ${ }^{(18-21,23-25)}$; three (23\%) used seminars ${ }^{(21-22,24)}$, and two (15\%) included videos ${ }^{(17,21)}$.

The educational strategies were diverse, including obtaining the opinion of the professionals, and creating a dynamic learning process ${ }^{(15-27)}$. In addition to lectures, active methodologies were used, which involved the learners and considered their experiences.

The use of adult learning principles, or andragogy, was mentioned in one of the articles as the methodology used to develop the training. The authors justify the choice, declaring that effective adult education needs to be relevant to the professional situation, should enable learners to take advantage of existing clinical experiences and knowledge, requires active involvement, and focuses on the problem ${ }^{(19)}$.

The Continuing Education in Health (Educação Permanente em Saúde - EPS) in Brazil, was instituted by the Ministry of Health as public policy, in 2004, and was modified in 2007. Based on Paulo Freire's concept of problematizing education, its consolidation depends on the fact that educational processes targeted at health workers are aimed at the transformation of professional practices and the organization of work itself. Therefore, EPS can be considered to be a guide for workers' development initiatives, as well as a strategy for transforming health practices ${ }^{(28)}$.

In order for an integrated education strategy to be defined as an EPS, it must be: embedded in the context of the practices in the everyday lives of organizations; reflexive and participatory, designed at the joint construction of strategies that seek solutions to the identified problems, as they do not exist without active subjects that create and modify them; inexhaustible, in which the various specific moments and modalities are combined in a global development project over time; oriented towards the development and institutional change of teams and social groups, which presupposes orienting it towards the transformation of collective practices. In addition, it must be strategic in a way that reaches a variety of subjects, such as service workers, community groups, and policy-makers in the system ${ }^{(29)}$.
This educational strategy uses problematization as an axis, associating distinct and specific actions. In this perspective, the EPS in service represents a dynamic tool in the institutional transformation, simplifying the understanding, valuation, and appropriation of the model of care indicated by the new programs, favoring the search for contextualized and integrated alternatives for the health care of the population ${ }^{(29)}$.

With regards to the professionals who received training on dementia, all the studies ( $n=13 ; 100 \%)$, declare received specific training ${ }^{(15-27)}$. Among the most frequently mentioned professionals were physicians $(n=13,100 \%)^{(15-27)}$, nurses $(n=12,92 \%)^{(15-26)}$, and social workers $(n=9,69 \%)^{(15-17,20-24,27)}$.

A descriptive-exploratory study aimed at exposing the international models of interprofessional care in dementia, defining a minimum number of PHC professionals, identified that to provide quality dementia care, a minimum team of professionals for team management and care coordination should be established with the following professional categories: general physician, nurse and social worker ${ }^{(15)}$.

Among the seven intervention studies, six (86\%) showed a statistically significant effect on the knowledge, skills, and attitudes of the professionals in providing care for those with dementias ${ }^{(18-19,}$ 21-22, 26-27), reinforcing the health education as an essential strategy for the improvement of work processes, and as a coordinated and quality response to the health needs of the population. Three (43\%) of theses studies were clinical trials, a method considered to be the gold standard among study types ${ }^{(4,6,12)}$.

A narrative review that aimed to determine the effects of educational interventions on dementia for primary care professionals, identified that five of six articles analyzed had significant effects after the interventions: a small group workshop and a decision support system increased the rates of detection of dementia; a two-hour interactive seminar increased the general practitioners' suspicion of dementia; adherence to the guidelines for dementia only improved when an educational intervention was combined with the appointment of care managers, and this combined intervention also improved the quality of life of patients and caregivers. Effects on knowledge and attitudes were lower. At first, the authors proposed a systematic review that was later changed to narrative review because of sample size $\mathrm{e}^{(24)}$.

Eleven (85\%) studies showed that, in addition to the development of the dementia education program, it is necessary to structure a continuing dementia management program with dynamic changes in work processes as a way to achieve better results. In addition, they recommended the constant restructuring of operational processes so that the team does not become

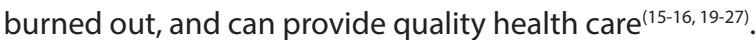

Therefore, it is necessary to develop a comprehensive program of interprofessional education in dementia. It should include theoretical classes for health professionals - undergraduate and graduate students - as well as advanced training through continuing education programs, addressing central topics: early diagnosis, post-diagnosis support, advanced care planning for patients and their caregivers, and effective collaborative care. Different educational methodologies are necessary, including participation in theoretical classes, s virtual platforms with theoretical distance classes, and the possibility of clarifying concerns, analyzing and discussing case studies with interdisciplinary participation, and discussions of cases attended by the team, on an ongoing basis ${ }^{(15)}$. 
The EPS in Brazil is an essential tool for changing PHC practices, as its systematic characteristic"goes from practice to information, from information to acquisition of skills and capabilities, from acquisition to programming of practical solutions". The problematization of educational practices and strategies considers: identification of problems with case studies, fieldwork, systematization of local data, construction and prioritization of problems; increasing knowledge through a study seminar, on-site internship, discussion groups, teleconferences, and interactive networks; development of specific skills of the staff, through training with supervision, specifically focused training, workshops to develop work projects; search for solutions and putting them into practice, with subsequent evaluation; using operational groups and local programming workshops to evaluate processes and results ${ }^{(29)}$.

\section{Limitations of the study}

Descriptive, experimental, and quasi-experimental studies were comparatively analyzed. Therefore, as a limitation of this study, the non-expansion of the publication time is indicated (greater than 15 years).

\section{Contributions to health and public policy}

Considering that Brazil is in a period of epidemiological transition, and the FHS is considered a priority manner for the reorganization of the PHC in the country, educational interventions with the family health teams in dementia are indicated. In addition, the structuring of a dementia management program that supports the teams and the system is recommended, to meet this health need without neglecting to watch other programs in force.

The evidence and information identified in this study provide support for planning the public health policies that meet the health needs of the elderly with dementia, and their caregivers, in the Brazilian cultural context.

\section{CONCLUSION}

The results of this integrative review showed that a combination of educational strategies on dementias were adopted with the PHC teams, as well as structured management programs for support, continuous education, and team monitoring for a more effective response of actions. These measures enabled us to identify significant improvements in knowledge, skills, and attitudes of the teams on providing care to patients with dementias.

\section{FUNDING}

This study is part of the research funded by the Foundation for Research Support of the State of São Paulo (Fundação de Amparo à Pesquisa do Estado de São Paulo - FAPESP), entitled: Educational meeds of professionals of the Family Health Strategy in the treatment of dementias. Process: 2016 / 01359-0.

\section{REFERENCES}

1. Burlá C, Camarano AA, Kanso S, Fernandes D, Nunes R. Panorama prospectivo das demências no Brasil: um enfoque demográfico. Ciênc Saúde Coletiva [Internet]. 2013[cited 2018 Jun 28];18(10):2949-56. Available from: http://www.scielo.br/pdf/csc/v18n10/v18n10a19.pdf

2. World Health Organization-WHO. Dementia: a public health priority [Internet]. 2012[cited 2015 Jun 29]. Available from: http://whqlibdoc. who.int/publications/2012/9789241564458_eng.pdf

3. Silva CF, Passos VMA, Barreto SM. Frequência e repercussão da sobrecarga de cuidadoras familiares de idosos com demência. Rev Bras Geriatr Gerontol [Internet]. 2012[cited 2018 Jun 28];15(4):707-31. Available from: http://www.scielo.br/pdf/rbgg/v15n4/11.pdf

4. Brodaty H, Woodward M, Boundy K, Ames D, Balshaw R. Prevalence and predictors of burden in caregivers of people with dementia. Am J Psychiatry Geriatr. 2014;22(8):756-65. doi: http://dx.doi.org/10.1016/j.jagp.2013.05.004

5. Springate BA, Tremont G. Dimensions of caregiver burden in dementia: impact of demographic, mood, and care recipient variables. Am J Psychiatry Geriatr [Internet]. 2014[cited 2018 Jun 28];22(3):294-300. Available from:https://www.ncbi.nlm.nih.gov/pmc/articles/ PMC3723767/pdf/nihms458971.pdf

6. Bauab JP, Emmel MLG. Mudanças no cotidiano de cuidadores de idosos em processo demencial. Rev Bras Geriatr Gerontol [Internet]. 2014[cited 2018 Jun 28];17(2):339-52. Available from: http://www.scielo.br/pdf/rbgg/v17n2/1809-9823-rbgg-17-02-00339.pdf

7. Abdollahpour I, Noroozian M, Nedjat S, Majdzadeh R. Caregiver burden and its determinants among the family members of patients with dementia in Iran. Int J Prev Med [Internet]. 2012[cited 2018 Jun 28];3(8):544-51. Available from: https://www.ncbi.nlm.nih.gov/pmc/articles/ PMC3429801/

8. Seima MD, Lenardt MH. A sobrecarga do cuidador familiar de idoso com Alzheimer. Textos Contextos [Internet]. 2011 [cited 2018 Jun 28];10(2):388-98. Available from: http://revistaseletronicas.pucrs.br/ojs/index.php/fass/article/view/9901

9. Santos RL, Sousa MFB, Brasil D, Dourado M. Intervenções de grupo para sobrecarga de cuidadores de pacientes com demência: uma revisão sistemática. Rev Psiq Clín [Internet]. 2011 [cited 2018 Jun 28];38(4):161-7. Available from: http://www.scielo.br/pdf/rpc/v38n4/a09v38n4

10. Tuero GC, Garre-Olmo J, Lòpez-Pousa S, Vilalta J, Limon E, Caja C. Percepción, actitudes y necesidades de los profesionales de atención primaria con relación al paciente con demencia. Atenc Primaria [Internet]. 2011 [cited 2018 Jun 28];43(11):585-94. Available from: http:// dx.doi.org/10.1016/j.aprim.2010.11.015

11. Ministério da Saúde (BR). Secretaria de Atenção à Saúde. Departamento de Atenção Básica. Envelhecimento e saúde da pessoa idosa [Internet]. Brasília; 2007[cited 2018 Jun 28]. Available from: http://bvsms.saude.gov.br/bvs/publicacoes/abcad19.pdf 
12. Secretaria de Saúde do Estado de São Paulo. Documento norteador: Unidade de Referência à Saúde do Idoso do Município de São Paulo. Secretaria Municipal da Saúde. Coordenação da Atenção Básica, Área Técnica de Saúde da Pessoa Idosa[Internet]. São Paulo; 2016[cited 2018 Jun 28]. Available from: http://www.prefeitura.sp.gov.br/cidade/secretarias/upload/saude/DOCUMENTONORTEADOR\%20 URSIversaofinal09012017.pdf

13. Souza MT, Silva MD, Carvalho R. Revisão integrativa: o que é e como fazer. Einstein [Internet]. 2010[cited 2018 Jun 28];8(1Pt1):102-6. Available from: http://www.scielo.br/pdf/eins/v8n1/pt_1679-4508-eins-8-1-0102.pdf

14. Mendes KDS, Silveira RCCP, Galvão CM. Revisão integrativa: método de pesquisa para a incorporação de evidências na saúde e na enfermagem. Texto Contexto Enferm [Internet]. 2008[cited 2018 Jun 28];17(4):758-64. Available from: http://www.scielo.br/pdf/tce/v17n4/18.pdf

15. Dreier-Wolfgramm A, Michalowsky B, Austrom MG, Van der Marck MA, lliffe S, Alder C, et al. Dementia care management in primary care: current collaborative care models and the case for interprofessional education. Z Gerontol Geriatr [Internet]. 2017 [citado 2018 Jul 08];50(Suppl 2):68-77. Available from: https://link.springer.com/content/pdf/10.1007\%2Fs00391-017-1220-8.pdf

16. Nieuwboer MS, Richters A, Van der Marck MA. Triple aim improvement for individuals, services and society in dementia care: the DementiaNet collaborative care approach. Z Gerontol Geriatr [Internet]. 2017[cited 2018 Jul 08];50(Suppl-2):78-83. Available from: https:// link.springer.com/content/pdf/10.1007\%2Fs00391-017-1196-4.pdf

17. Davies N, Hopwood J. The many faces of dementia: is an online course beneficial for GPs? Br J Gen Pract [Internet]. 2017 [cited 2018 Jul 08];67(654):27. Available from: https://www.ncbi.nlm.nih.gov/pmc/articles/PMC5198593/pdf/bjgpjan-2017-67-654-27.pdf

18. Wang Y, Xiao LD, Ullah S, Ele GP, De Bellis A. Evaluation of a nurse-led dementia education and knowledge translation programme in primary care: a cluster randomized controlled trial. Nurse Educ Today [Internet]. 2017[cited 2018 Jul 08];49:1-7. Available from: https://www. sciencedirect.com/science/article/pii/S0260691716302544

19. Edwards R, Voss SE, lliffe S. The development and evaluation of an educational intervention for primary care promoting person-centred responses to dementia. Dementia [Internet]. 2015[cited 2018 Jul 08];14(4):468-82. Available from: http://journals.sagepub.com/doi/ pdf/10.1177/1471301213499768

20. Wilcock J, lliffe S, Griffin M, Jain P, Thuné-Boyle I, et al. Tailored educational intervention for primary care to improve the management of dementia: the EVIDEM-ED cluster randomized controlled trial. Trials [Internet]. 2013[cited 2018 Jul 08];14:397. Available from: https://www. ncbi.nlm.nih.gov/pmc/articles/PMC4222692/pdf/1745-6215-14-397.pdf

21. Lee L, Weston WW, Hillier LM. Developing memory clinics in primary care: an evidence-based interprofessional program of continuing professional development. J Contin Educ Health Prof [Internet]. 2013[cited 2018 Jul 08];33(1):24-32. Available from: https://onlinelibrary. wiley.com/doi/pdf/10.1002/chp.21163

22. Galvin JE, Meuser TM, Morris JC. Improving physician awareness of Alzheimer disease and enhancing recruitment: the Clinician Partners Program. Alzheimer Dis Assoc Disord [Internet]. 2012[cited 2018 Jul 08];26(1):61-7. Available from: https://www.ncbi.nlm.nih.gov/pmc/ articles/PMC3288449/pdf/nihms332853.pdf

23. Lee L, Kasperski MJ, Weston WW. Building capacity for dementia care: training program to develop primary care memory clinics. Can Fam Physician [Internet]. 2011 [cited 2018 Jul 08];57(7):249-52. Available from: https://www.ncbi.nlm.nih.gov/pmc/articles/PMC3135463/ pdf/057e249.pdf

24. Perry M, Drašković I, Lucassen P, Vernooij-Dassen M, Van Achterberg T, Olde Rikkert M. Effects of educational interventions on primary dementia care: a systematic review. Int J Geriatr Psychiatry [Internet]. 2011 [cited 2018 Jul 08];26(1):1-11. Available from: https:// onlinelibrary.wiley.com/doi/epdf/10.1002/gps.2479

25. Perry M, Draskovic I, Van Achterberg T, Borm GF, Van Eijken MI, Lucassen P, et al. Can an EASYcare based dementia training programme improve diagnostic assessment and management of dementia by general practitioners and primary care nurses? the design of a randomised controlled trial. BMC Health Serv Res [Internet]. 2008[cited 2018 Jul 08];8:71. Available from: https://www.ncbi.nlm.nih.gov/ pmc/articles/PMC2391160/pdf/1472-6963-8-71.pdf

26. Chodosh J, Berry E, Lee M, Connor K, DeMonte R, Ganiats T, et al. Effect of a dementia care management intervention on primary care provider knowledge, attitudes, and perceptions of quality of care. J Am Geriatr Soc [Internet]. 2006[cited 2018 Jul 08];54(2):311-7. Available from: https://onlinelibrary.wiley.com/doi/epdf/10.1111/j.1532-5415.2005.00564.x

27. Cherry DL, Vickrey BG, Schwankovsky L, Heck E, Plauchm M, Yep R. Interventions to improve quality of care: the Kaiser Permanentealzheimer's Association Dementia Care Project. Am J Manag Care [Internet]. 2004[cited 2018 Jul 08];10(8):553-60. Available from: https:// www.ajmc.com/pubMed.php?pii=2656

28. Silva LAA, Ferraz F, Lino MM, Backes VMS, Schmidt SMS. Educação permanente em saúde e no trabalho de enfermagem: perspectiva de uma práxis transformadora. Rev Gaúcha Enferm [Internet]. 2010[cited 2018 Jul 21];31(3):557-61. Available from: http://www.scielo.br/pdf/ rgenf/v31n3/v31n3a21.pdf

29. Ministério da Saúde (BR). Secretaria de Gestão do Trabalho e da Educação na Saúde. Departamento de Gestão da Educação em Saúde. Política Nacional de Educação Permanente em Saúde [Internet]. Brasília; 2009[cited 2018 Jul 21]. Available from: http://bvsms.saude.gov.br/ bvs/publicacoes/politica_nacional_educacao_permanente_saude.pdf 